\title{
Conflict mobilization communities in social media as a soft power tool: problematization environmental risks
}

\author{
Larisa Rebrina* \\ Volgograd State University, pr. Universitetskij 100, 400062 Volgograd, Russia
}

\begin{abstract}
The object of the study is the protest communication practices of conflict mobilization in 2012-2021 by environmental communities in Russian-language social networks. Civil society is a significant actor in environmental policy. Social media as a soft power tool plays an important role today in informing, educating society about the environment and shaping a protesting regional environmental agenda. The systemcommunicative approach explores the patterns of discursive problematisation of environmental risks within the framework of civic political participation. Authors describe the types of publications constituting the content of environmental mobilization communities; analyse thematic dominants to identify frequent environmental threats constructed by the addressants of the publications; identify and systematise the strategies, tactics and relevant language tools used to problematise fragments of environmental reality; examine regular means of creating and maintaining online solidarity in environmental communities of conflict mobilization.
\end{abstract}

\section{Introduction}

Along with the state and business, civil society is a significant actor in all politics. Today, civic participation in the environmental sphere is developing actively, and environmental movements are building their political capacity. However, in our country, the very system of civic participation in this sphere, designed to complement and develop government regulation and to help protect the right to a healthy environment, is still under construction, nevertheless reflecting the greening of public consciousness. We should note the important role of civic participation in informing, educating society about the environment and shaping the environmental agenda, especially the protest agenda and the regional agenda. The object of the study is protest communication practices of conflict mobilization (consolidation mobilization against) 2012-2021 in Russian-language social networks, bringing participants together around an environmental problem that demands a solution to an environmental situation, against environmentally damaging decisions and plans. Social networks are nowadays a soft power and political influence tool, a space for effective implementation of political technologies for the generation and transmission of given

\footnotetext{
*Corresponding author: LNRebrina@volsu.ru
} 
meanings within the framework of retinal communication and the formation of public consciousness. The research from the perspective of the systems-communicative approach aims to describe the patterns of the discursive construction of the environmental agenda and environmental problems in protest communication practices in social networks. Linguistics seems capable of contributing to the study of these issues, including the impact of new media and communication technologies on the political participation of citizens.

\section{Materials and Methods}

We consider protest communication as a communicative system, implementing the conjunction of the media and political spheres, characterized by specific genre features, collective-personal (composition of participants, ways of construction of the addressee, addressant, solidarity, relevant strategies and tactics of participants) and subject (proactivereactive nature, the set of themed objects, ways of agenda formation, problematization of reality) parameters. $[1 ; 2 ; 3 ; 4]$. Contemporary researchers note the systemiccommunicative autonomy, self-validation of protest (substituting problematisation of fragments of objective reality from the socio-cultural positions of protest actors observing reality, and the autorepresentation of protest as eliminating a constructed threat in various forms of competition for resources with diverse institutions), which involves a combination of traditional structural-critical and resource-mobilization approaches [1]. Protest can have a constructive/destructive, autonomous/mobilising, active/passive, conventional/unconventional character, reflecting different levels of interaction between citizens and authorities. Protest practices are institutionalised/non-institutionalised practices of conflict resolution as an acute divergence of the parties' interests; conflict, if properly communicated, can be a constructive force that explicates contradictions and optimises the search for solutions [5]. Contemporary protest reflects the link between socio-cultural transformations and technological changes, primarily information and communication technologies $[3 ; 6 ; 7 ; 8]$.

Conflict mobilization builds on social conflict and negative identity, aims to solidarize and induce the addressees of influence to take joint desirable social action against the constructed and presented danger; it features a number of developmental stages (an information wave generating protest sentiment; formation of emotional internet solidarity; articulation of a decision on joint online/offline protest activity and its form; organisational action; post communication) [see 9; 10].

The formation of mobilization communities in social networks stems from the need to target the consolidating effect $[11 ; 12 ; 13]$ against the background of the existing selective, self-imposed filters (limitation by the referential field of the Internet user) informing network users [9] and the advantages of communities in social networks (wide coverage and rapid circulation of information due to voluntary association and horizontal selforganisation, effective interactive tools offered, multiplication of addressants producing content, cross-border) [7; 14]. As for the system of subscriptions, self-imposed filters, we should mention that they contribute to the cultivated avoidance of contradictions by erecting an individual comfort zone, adjusting content, and thereby constructing a social reality to suit oneself. Mobilization communities on social media facilitate segmentation and aggregation of participants according to similar positions, interests, aggregation of news and content sharing of certain topics, individualisation of addressee and information. Such communities are heterogeneous in composition, bringing together consumers and active content producers, participants who differ in their perceptions of the Internet and civic political participation, the regularity of participation, and the prevalence of weak and strong ties $[3 ; 15]$. 
Table 1 presents the environmental mobilization protest communities on social media, whose content served as a source of practical material.

Table 1. Researched environmental mobilization protest communities on social media

\begin{tabular}{|c|c|c|}
\hline social network, community name, purpose of the protest & $\begin{array}{l}\text { date of organisation, } \\
\text { status, reference }\end{array}$ & $\begin{array}{l}\text { number of } \\
\text { subscribers } \\
\text { /participan } \\
\text { ts }\end{array}$ \\
\hline $\begin{array}{l}\text { VKontatke, We are against stink and incinerators in the } \\
\text { north of St. Petersburg (against air pollution in north- } \\
\text { west St. Petersburg; Novoselki landfill, Severny sewage } \\
\text { sludge landfill, asphalt plants in the Kolomyagi zone, } \\
\text { sludge incineration plant in Lakhta, waste processing } \\
\text { plant placement in the Kamenka zone) }\end{array}$ & $\begin{array}{l}2016, \quad \text { open, } \\
\text { https://vk.com/spb_st } \\
\text { op_reek }\end{array}$ & 9353 \\
\hline $\begin{array}{l}\text { Vkontakte, Sychovo is against (against the construction } \\
\text { and commissioning of a new landfill in the vicinity of } \\
\text { Sychovo and Shchelkanovo) }\end{array}$ & $\begin{array}{l}2018, \quad \text { open, } \\
\text { https://vk.com/sch_po } \\
\text { ligon }\end{array}$ & 2961 \\
\hline $\begin{array}{l}\text { Against Titanium Polymer (against the construction of a } \\
\text { polyethylene terephthalate plant in Moglino) }\end{array}$ & $\begin{array}{l}2019, \quad \text { public, } \\
\text { https://www.facebook } \\
\text {.com/groups/pskovpro } \\
\text { tiv/about }\end{array}$ & 280 \\
\hline $\begin{array}{l}\text { VKontakte, Titan-Polymer }- \text { PSKOVICIANS } \\
\text { AREAGAINST! (against the construction of a chemical } \\
\text { plant) }\end{array}$ & $\begin{array}{l}2019, \quad \text { open, } \\
\text { https://vk.com/protivti } \\
\text { tana }\end{array}$ & 2359 \\
\hline $\begin{array}{l}\text { Facebook, Brest against the construction of a leaded } \\
\text { battery plant (against the construction of a battery plant } \\
\text { near Brest) }\end{array}$ & $\begin{array}{l}2018, \quad \text { public, } \\
\text { https://www.facebook } \\
\text {.com/groups/1687888 } \\
\text { 20292870/about }\end{array}$ & 5068 \\
\hline $\begin{array}{l}\text { Facebook, For a Healthy Vladikavkaz - Against } \\
\text { Electrozinc! (against Electrozinc's lead-zinc plant) }\end{array}$ & $\begin{array}{l}2016, \quad \text { public, } \\
\text { https://www.facebook } \\
\text {.com/groups/protivec/ } \\
\text { about }\end{array}$ & 804 \\
\hline 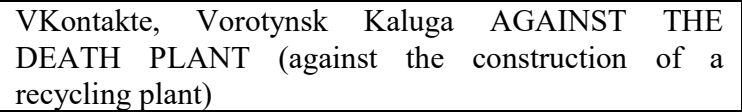 & $\begin{array}{l}2019, \quad \text { open, } \\
\text { https://vk.com/voroty } \\
\text { nsk_kaluga_prozavod }\end{array}$ & 1678 \\
\hline $\begin{array}{l}\text { Vkontakte, Ghost of the Future against the incinerators. } \\
\text { Kolpinsky district (against emissions from the Sveza } \\
\text { Ust-Izhora incinerators) }\end{array}$ & $\begin{array}{l}\text { 2020, open, } \\
\text { https://vk.com/no_tras } \\
\text { h1 }\end{array}$ & 3756 \\
\hline $\begin{array}{l}\text { Vkontakte, Against the landfill in Pervomayskoye } \\
\text { (against the organisation of the landfill north of } \\
\text { Ogonyki village) }\end{array}$ & $\begin{array}{l}2016, \quad \text { open, } \\
\text { https://vk.com/protiv_- } \\
\text { svalki_v_pervomaisk } \\
\text { om }\end{array}$ & 2862 \\
\hline $\begin{array}{l}\text { Vkontakte, We are against the landfill on Shies (against } \\
\text { the landfill in Leninsky District of Arkhangelsk Oblast, } \\
\text { construction of a solid waste processing plant) }\end{array}$ & $\begin{array}{l}2019, \quad \text { open, } \\
\text { https://vk.com/great__ } \\
\text { food }\end{array}$ & 13575 \\
\hline $\begin{array}{l}\text { Vkontakte, Against the construction of a port in } \\
\text { Primorsk (against the construction of a universal } \\
\text { transhipment complex in Primorsk and Ermilovo } \\
\text { village) }\end{array}$ & $\begin{array}{l}\text { 2019, open, } \\
\text { https://vk.com/protivp } \\
\text { orta }\end{array}$ & 4435 \\
\hline $\begin{array}{l}\text { Vkontakte, Against transit through Nizhnyaya } \\
\text { Yeltsovka! (against the construction of a motorway } \\
\text { bypass in the Sovetsky District of Novosibirsk) }\end{array}$ & $\begin{array}{l}\text { 2019, open, } \\
\text { https://vk.com/net_tra } \\
\text { nsitu_ne }\end{array}$ & 860 \\
\hline
\end{tabular}


Table 1. Continued Facebook, Against incinerators, FOR separate waste collection and recycling! (against the construction of incinerators)

\begin{tabular}{l|l|} 
2012, public, & 158 \\
https://www.facebook & \\
.com/groups/stop.burn & \\
ing.trash/ &
\end{tabular}

The sample size was 1,020 publications.

We consider the practices of conflictual environmental mobilization in social media as an integrative hyper-genre: polyfunctional (informing, evaluating, inciting, agitating and propaganda), combining features of different discourses (media, political, everyday, internet discourse), stylistically and genre-syncretic (bookish and colloquial speech, signs of open writing and internet forum).

This study aims to characterise the subject systemic-communicative dimension of environmental protest, describing patterns of discursive problematisation in the example of environmental communities of conflict mobilization in social media. It addresses the following tasks: describing the types of publications, constituting content communities; correlating solidarity and non-solidarity reactions of community members to publications for assessing the implementation of discursive environmental problematisation in the communities under study; analysing thematic dominants to identify frequent constructs of environmental threats from the observer perspective (ordinary citizens - group participants); describing strategies and tactics for problematising fragments of environmental reality; identifying regular means of creating/maintaining online solidarity in communities.

\section{Results and Discussion}

The content of the environmental conflict mobilization communities studied is constituted by different types of publications: non-community publications that are shared within the community; publications produced by community members and aimed at consolidating information against the opponent, building emotional solidarity; and direct mobilization publications on behalf of the community, encouraging participation in protest action and organising participation. The interaction relies on informational (administered information of selective nature regarding the objects of thematization), communicative (making public the object of thematisation and the product of solidarity), psychological (influencing motivation, emotions), educational (influencing values, behaviour, awareness and political thinking), organisational (providing necessary conditions and tools for consolidation) modes [see 16].

The analysis, systematization of thematic dominants and quantitative calculations of the publications of the studied environmental mobilization communities in social networks indicate that from the position of the most active citizens (community initiators, content producers) there are the following areas-sources of problematic objects: construction of harmful production (incinerators, asphalt and concrete, waste processing plants, solid waste processing, lead-zinc enterprises, plants for production of lead-coated batteries, etc.) $-68.42 \%$; organization of landfills/waste dumps $-26.32 \%$; construction of highways $-5.26 \%$. At the same time, an account of the number of participants united in a community by a particular problem/threat, demonstrating a similar negative identity, and an analysis of the interactive reactions of group members in support of publications systematised according to named thematic dominants indicates approximately the same interest in two main areas: from the perspective of the mass addressee-consumer of content, the following situations/circumstances of construction/exploitation are the most environmentally 
problematic, causing concern and protest sentiments of citizens are the following situations/circumstances- construction/operation of harmful production (support $58.34 \%$ of the total number of participants in the communities studied); organisation of landfills, rubbish/waste dumps (40.45\%). The targeted and successful discursive construction of an environmental situation with a threat index in communities of conflictual environmental mobilization is evident from the unambiguous dominance of solidarity reactions by addressees, indicating a planned perception, sharing of knowledge and attitude among community participants.

Establishing the environmental agenda (justifying and presenting a circumstance, phenomenon or situation as dangerous and requiring a solution) involves a strategy of supplying the object of thematization with a threat index.

One of the most frequent tactics of the described strategy is a direct negative assessment of the current state of affairs $(23.61 \%)$, characterised by the use of evaluation units with negative semantics, verbs in the present tense, lexemes with the temporal semantics of "present": Landfills are monstrously maintained by municipalities [17, 02.09.2021]; Dmitry Baranov: They will put some kind of class 4 hazard instead of class 1. Now they do not hesitate and are making a mess of things. All these Vedernikovs, Moscow bandits ... $[18,23.07 .2021]$.

The next tactic actively used is to indirectly indicate dissatisfaction with the state of affairs by directly addressing/calling on members of the mobilization community to change the situation, to counteract $(19.33 \%)$. The relevant language means - appeals, incentive sentences, performatives, personal and possessive pronouns in the 2 nd person plural and 1st person plural, some determinative pronouns (for example: all, every), words with the semantics of jointness: We call upon all of you to write a statement to the Prosecutor's Office of the Komi Republic concerning the legality of the OMON and police actions to escort fuel tankers to the \#Shies [19, 13.11.2019]; Dear supporters! We ask for help from all those involved in defending Shies [19, 13.11.2019].

The next tactic used - the explication of the dangerous consequences of the phenomenon/situation (14.86\%). Its realisation presupposes the use of lexical units (LUs) expressing negative evaluation, future tense verbs, adverbs and prepositions with the temporal semantics of consequence, and LUs belonging to the semantic field of "harm". For example: With such cargo turnover, the ecology of our city and neighbouring territories will be irreparably damaged, and there will be a serious danger to people's health... [20]; if there is a problem at this plant or a minimal leak of sulfur vapour or lead dust - it will cover the whole city, the critical area is up to $15 \mathrm{~km} \ldots$ and in 10 years near this plant, we will build a hospital for oncology patients [21].

To justify a negative assessment of the state of affairs, they also use as an indirect argument the tactic of a direct negative assessment of their opponent's qualities (17.16\%). The relevant linguistic means are LUs with negative semantics, anthroponyms, and the designation of professions and positions; the references to the opponent are also frequent: Once again, we observe the ignorance of the staff of the oversight body [19, 14.08.2019]; Volunteers ... negotiate with processors, but officials are clearly not capable of this. But they are capable of polluting rivers, soil and air with insane decisions. ... Gentlemen officials, are you really so dull or do you have only mercantile priorities? [22, 07.06.2021].

Related to the previous tactic is the tactic of blaming the opponent, initiating the addressee's assessment of the situation as threatening, dangerous (14.21\%). This tactic involves the use of anthroponyms, the designation of a subject of power, LUs with negative semantics, and LUs from the semantic fields of "guilt" and "condemnation". For example: Neither Parfenov nor Shapsha has done anything to make rubbish segregation mandatory ... Neither of them did anything to conclude contracts with recyclers... [22, 07.06.2021]. 
2021]; Everything happened precisely because the swindlers from "MPBO-2", under the watchful eye of the profile vice-governor Nikolay Bondarenko and Sergey Malinin, head of the Committee for Public Works, continued to quietly transport duds in the form of combustible waste to the landfill - and as a result they themselves created ideal conditions for a fire [23, 17.08.2021].

A regular tactic to implement this strategy is a declaration on behalf of the community against the threat as a community goal (7.38\%), which contributes to the mass recipient sharing a negative assessment of the presented situation (usually offered in the "information" tab or a fixed entry at the top of the page in the "discussion" tab). The relevant means within this tactic are lexical units (LUs) of the semantic fields "achievement" and "opposition", the inclusive 1st person plural pronoun, LU with the semantics of oughtness, synonyms of the word problem, community/group designations. For example: Community of residents of Primorsky ... and other districts of St. Petersburg and the Leningrad region, who are tired of enduring the regular stench of rotting waste ..., the fumes from asphalt plants and sludge incineration. We want to get the authorities to solve these problems and prevent the emergence of ... even more dangerous sources of pollution ... [23]; GROUP'S GOAL: ELECTROCINIC MUST KEEP THE REPUBLIC! [24].

An indirect argument in presenting some circumstance to the addressee as a threat also uses the tactic of stating the opposing interests and needs of citizens and the opponent (3.45\%); the relevant linguistic means - antithetic conjunctions, syntactic parallelism, antonyms, LUs with opposite evaluative semantics and other means that implement the contrast: for someone this pipe is a symbol of future cash flow, and for someone it is a symbol of a vanishing hope for good ecology and strong health [22, 26. 07.07.2021]; Vladimir Kozlov: Kremlin guys are doing a good job - money from natural resources trade to Moscow, while dumpsters are taken away... It's time to end it))) POMORIE IS NOT $\boldsymbol{A}$ DUMP! [19, 06.11.2019].

Alongside the informative, propagandistic, directive and regulative functions, the evaluative function is the most important obligatory feature of the communicative practices described, realised through the strategy of presenting evaluations. We should note that assessment can be offered to community members as subjective, individual (unsupported) and as relying on other resources, such as norms, traditions, expert opinion, etc. (supported).

One of the most frequent tactics of this strategy is the tactic of broadcasting evaluation as shared by multiple subjects (34.67\%), which implies extensive identification of the addressant with the addressee, for example, through the use of inclusive pronouns, the first person plural possessive pronoun, a number of definitional pronouns (all, whole, every, any, whatever), collective signs, collective subject names and the use of LUs with an evaluative semantics. For example: We all know about the lawless acts committed there on October 23 [19, 13.11.2019]; Residents are convinced that the connivance of the landfill reclamation organisation is to blame for the fire [23, 21.08.2021]; "Time Bomb", or "Monster". This is how Vladikavkaz residents call the Elektrotsink plant, which stands right in the city centre [24, 31.08.2021].

A common tactic is to present the addressee with an individual evaluation (26.81\%); frequent are personal and possessive pronouns in the singular, LUs with evaluative semantics, verbs of speech activity and exclamatory sentences: Karina Korzhova: I am sick of this lie and disorder! I won't vote now on principle! No adequate people in power! Just to steal and line their own pockets! [20, 04.09.2021]; Natalia Ivanova: I don't know who the guilty person is, but I know that it's wrong, it would be nice to find out who is responsible [23, 17.08.2021] 
The next way of presenting evaluation - the tactic of broadcasting evaluation as a moral axiom $(23.13 \%)$, which involves appealing to common moral experiences, norms and widespread perceptions. Relevant linguistic means - LUs with evaluative semantics, abstract nouns, cliches, proverbs, idioms, stable expressions. For example: Tatiana Chulkova: they do not know what they are doing. They will be damned to the seventh tribe. They cut everything down. Petersburg will suffocate. These forests and lakes are protected Do not touch them. Where is the prosecution to put them all in prison? Devils what will they leave behind... [20, 05.09.2021] (appeal to moral norms: one should not touch the untouchable, one should leave behind the good, one should think about consequences); Dmitry Poplavsky: a country of barbarians who value nothing... neither freedom, nor nature, nor the homeland... only dough on their mind... [20, 05.09.2021].

The last tactic revealed is the reinforcement of the evaluation presented to the addressee with a reference to authority $(15.39 \%)$, which implies the use of LUs with evaluative semantics, anthroponyms, designations of professions, positions, organizations, verbs of speech-thought activity: Conclusion of public ecological expertise of the project documentation "Primorsky universal transhipment complex". ... brief paraphrase: ... the project will be neither safe ecologically, nor technically [20, 01.07.2021]; Marina Viktorovna: the presenter had better remember what academician Yablokov said - the anthropogenic load on the Gulf of Finland has long been exceeded! [20, 01.07.2021].

The strategies and tactics mentioned in the description of the strategies and tactics, identification with community members, LUs with the semantics of joint action and unification, appeals, messages with broad addressing, as well as compliments from the community and its members to participants and active post communication are regular means of creating/maintaining online solidarity in the studied environmental communities of conflict mobilization.

\section{Conclusion}

Environmental communities of conflict mobilization in Russian-language social networks, whose content is constituted by external and internal publications of indirect and direct mobilization, use informational, communicative, psychological, educational and organisational modes of mobilization, correlating with the main stages of the latter; the impact is framed by the concept of "I-we-they", involving the construction of negative and positive group identities, through solidarising group self-representations and consolidating oppositions. From the perspective of the most active citizens producing their own content and content consumers, the most problematic situations correlating with the frequency objects of thematization are the construction/operation of harmful production and the organisation of landfills or dumping sites for rubbish, hazardous waste. Frequent ways of forming virtual solidarity are wide identification of the addressant with community members, building semantic fields of jointness, unity; wide addressing of appeals and messages; and active post-communication. The discursive construction of the ecological situation with a threat index in the described communicative practices is confirmed by the unambiguous dominance of solidarity reactions of community participants, who share the transmitted knowledge, attitudes and emotional experiences. The discursive problematisation of environmental risks in conflict mobilization in social media is predominantly realised through supported or unsupported direct negative assessment of the current situation, with a predominant appeal to grassroots positions, moral norms and values, individual worldviews or, less frequently, -to the opinion of authority; through broad appeals to community members "to stand against"; negative evaluation and blaming the opponent; pointing out the dangerous consequences of the current state of affairs; declaring the goal of environmental community conflict mobilization. 


\section{Acknowledgements}

The reported study was funded by the Russian Foundation for Basic Research, project number 20-012-00193.

\section{References}

1. R. E. Barash, A. Yu. Antonovsky, Philosophical Journal, 11(2), 91-105 (2018)

2. S. V. Paulov, Bulletin of the Chita State University, 1(4), 26-30 (2008)

3. L. N. Rebrina, N. L. Shamne, Nauchnyi dialog, 3, 151-167 (2020)

4. Z. Oniszczuk, Studiów Medioznawczych, 4(47), 1-15 (2011)

5. R. Fisher, W. Ury, B. Patton, Getting to Yes: Negotiating Agreement Without Giving, New York, Penguin Books (2011)

6. L. V. Kazimirchik, Theory and practice of social development, 1, 99-103 (2014)

7. V. I. Kurbatov, Humanitarians of the South of Russia, 6(6), 173-181 (2017)

8. G. Small, G. Vorgan, I-Brain: Surviving the Technological Alteration of the Modern Mind (New York : Harper-Collins, 2009)

9. A. Vanka, I. Ksenofontova, I. Tartakovskaya, Inter, 7, 44-73 (2014)

10. L. N. Rebrina, Nauchnyi dialog, 5, 115-139 (2021)

11. I. A. Gladchenko, Scientific and Technical Bulletin of SPbSPU. Humanities and social sciences, 10(2), 30-43 (2019)

12. A. S. Sherstobitov, A. Bryansk, Questions of theory and practice, 10(36)/I, 196-202 (2013)

13. O. N. Yanickij, So ک̧siologicheskie Issledovaniia, 6, 3-12 (2012)

14. A. V. Kirka, Vestnik Gosudarstvennogo universiteta upravleniya, 4, 47-51 (2012)

15. S. V. Dokuka, Communication in social online networks as a factor of protest mobilization in Russia (2014)

16. Yu. B. Kinyasheva, Humanities, 3, 3-10 (2018)

17. PTch - VKontakte, Against transit through Nizhnyaya Yeltsovka, https://vk.com/net_transitu_ne

18. PTP - $\quad$ Facebook, Against "titanium-polymer", https://www.facebook.com/groups/pskovprotiv

19. MPS - VKontakte, We are against the landfill on Shies, https://vk.com/great_food

20. PSP - VKontakte, Against the construction of the port in Primorsk, https://vk.com/protivporta

21. BPS - Facebook, Brest against the construction of a lead-acid battery plant, https://www.facebook.com/groups/168788820292870/about

22. PMZ - Facebook, Protiv musoroszhigatel'nyh zavodov, Against incinerators, FOR separate collection and recycling of waste, https://www.facebook.com/groups/stop.burning.trash

23. MPV - VKontakte, We are against the stench and incineration plants in the north of St. Petersburg, https://vk.com/spb_stop_reek

24. ZZV - Facebook, For healthy Vladikavkaz - against "Electrozinc"!, https://www.facebook.com/groups/protivec/about 